John Carroll University

Carroll Collected

Biology

$12-2007$

\title{
Diatom Species Composition and Ecology of the Animas River Watershed, Colorado, USA
}

Gerald V. Sgro

John B. Poole

Jeffrey R. Johansen

John Carroll University, johansen@jcu.edu

Follow this and additional works at: http://collected.jcu.edu/biol-facpub

Part of the Biology Commons

\section{Recommended Citation}

Sgro, Gerald V.; Poole, John B.; and Johansen, Jeffrey R., "Diatom Species Composition and Ecology of the Animas River Watershed, Colorado, USA" (2007). Biology. 2.

http://collected.jcu.edu/biol-facpub/2

This Article is brought to you for free and open access by Carroll Collected. It has been accepted for inclusion in Biology by an authorized administrator of Carroll Collected. For more information, please contact connell@jcu.edu. 
Western North American Naturalist 67(4), (C) 2007, pp. 510-519

\title{
DIATOM SPECIES COMPOSITION AND ECOLOGY OF THE ANIMAS RIVER WATERSHED, COLORADO, USA
}

\author{
Gerald V. Sgro ${ }^{1,3}$, John B. Poole ${ }^{2}$, and Jeffery R. Johansen ${ }^{1}$
}

\begin{abstract}
The diatom flora of selected sites in the Animas River Watershed, San Juan County, Colorado, was studied. Eighty diatom taxa were identified from 10 sites: 8 sites on the Animas River and 1 site each on the Cement and Cascade tributaries. The sample diatom abundance was dominated by Achnanthidium minutissimum, Encyonema silesiacum, Aulacoseira distans, Hannaea arcus, and Diatoma mesodon. The presence of teratologic specimens of Fragilaria and Achnanthidium in the samples indicated the possibility of metals contamination. Diatom diversity was low and LangeBertalot pollution index scores indicated little organic pollution evidenced from diatom composition. There was evidence that diatom composition at the sites was differentially affected by $\mathrm{pH}$ and possibly by the concentrations of $\mathrm{Zn}$ alone or in combination with $\mathrm{Cd}, \mathrm{Cu}$, and $\mathrm{Fe}$.
\end{abstract}

Key words: diatoms, periphyton, Animas River, abandoned mine lands, heavy metals pollution, pollution indicator.

The Animas River is an important water resource in southwestern Colorado. This system, with headwaters above tree line, flows through the community of Silverton, Colorado, continues along the Weminuche Wilderness Area, and then through the urban area of Durango, Colorado. Historically, the river has been valued for recreation, wildlife habitat, and aesthetics, as well as for its potential as a source for drinking water and commercial use. The river system currently suffers impairments in appearance and water quality because of historic mining activity (von Guerard et al. 2004). Increasing anthropogenic pressure in the watershed further threatens the river with increased nutrient loading and other forms of pollution.

Sustaining an acceptable water quality for the river necessitates a thorough understanding of the system. Work has been done, including investigations of fish and macroinvertebrate populations, to characterize the Animas River Watershed and individual sites in order to understand the adverse effects of mineralized deposits released from abandoned mines, any effects present before mining activity, and other impacts that limit the sustainability of a desired ecosystem (von Guerard et al. 2004).

Diatoms have been used in the past to assess the effects of mine drainage and organic pollu- tion in mountain streams (Bahls 1993, Gerritsen and Bowman 1994, McFarland et al. 1997, Niyogi et al. 2002). The characteristics of diatom periphyton community structure and diatoms' sensitivity to water chemistry parameters make diatoms valuable for defining and characterizing the Animas River in regard to its water quality, ecology, and role in the watershed. Diatoms are ubiquitous in the Animas River system and represent the primary producers of the river; hence, they are critical to all other life forms in the system. Diatoms are also a major factor in nutrient cycling and energy flow and are critical to the balance and stability of aquatic systems (Stevenson and Lowe 1986). The abundance of diatoms may reflect environmental degradation and decline in water quality in mountain streams (Bahls 1993, Gerritsen and Bowman 1994).

The purposes of this study were to survey and assess the health of the periphytic (attached) diatom flora at 10 sites in the Upper Animas River Watershed and to create baseline data for future reference. Effects of organic pollution were assessed using indicator species from the Lange-Bertalot pollution index (Lange-Bertalot 1979). Possible effects of $\mathrm{pH}$, zinc $(\mathrm{Zn})$, cadmium $(\mathrm{Cd})$, iron $(\mathrm{Fe})$, and copper $(\mathrm{Cu})$ on diatom community structure were investigated with an exploratory graphical approach.

\footnotetext{
${ }^{1}$ Department of Biology, John Carroll University, University Heights, OH 44118 ${ }^{2}$ Silverton Mountain School, Silverton, CO 81433.

${ }^{3}$ E-mail: jsgro@jcu.edu
} 


\section{Study Area}

The Animas River has headwaters at $>4300$ $\mathrm{m}$ asl. It carves a U-shaped valley through the San Juan Mountains. In the Animas River Watershed near Silverton, Colorado, Precambrian crystalline basement is overlain by Paleozoic to Tertiary sedimentary rocks and Tertiary volcanic rocks. These formations are often exposed by high topographic relief. Four historic mining districts are situated in the upper portions of the Animas River Watershed: the Eureka District, the Red Mountain District, the Silverton District, and the Ice Lake District. Historically, the lower reach of the Animas River below Elk Creek has been less affected by mining activity than the upper reach (von Guerard et al. 2004).

\section{Methods}

\section{Diatom Collection and Enumeration}

Sampling for this study was done at 8 sites along the Animas River near the confluences with the following tributaries: South Fork of Eureka Creek, Cunningham Creek, Cement Creek, South Mineral Creek, Deer Creek, Elk Creek, Needle Creek, and Cascade Creek. Additionally, samples were collected on the Cement and Cascade tributaries near their respective confluences with the Animas River. The sites were selected because they lie at the confluences of the major tributaries of the upper Animas River within the Abandoned Mine Lands Initiative study area (von Guerard et al. 2004; except for the Needle and Cascade sites, which lie downstream from the study area) for which water chemistry data were available (Simon et al. 2001). These upper tributaries are possible sources of metals loading for the Animas River, while the Needle and Cascade sites represent less-impacted sections of the river.

The sites ranged from approximately $3 \mathrm{~m}$ to $10 \mathrm{~m}$ wide, increasing from Eureka, the most upstream site (approximately $3 \mathrm{~m}$ wide), to Cascade, the most downstream site (approximately $30 \mathrm{~m}$ wide). Substrate at all sites consisted of cobble. The riparian area at all sites consisted of cobble-lined banks with tundra vegetation at the Eureka site; willow and other shrubby vegetation at the Cunningham, Deer, Elk, Needle, and Cascade sites; and grassy meadow vegetation at the Cement and
Mineral sites. Stream depth ranged from $<1 \mathrm{~m}$ to $2 \mathrm{~m}$, with depth increasing from upstream to downstream sites. Historic and real-time stream flow data are available on the internet (http:// co.water.usgs.gov).

Diatom samples for this study were collected on 4-7 August 2005. A sampling unit transect was established across the wadable portion of each study stream approximately $10 \mathrm{~m}$ above the confluence with the intersecting stream. We collected 10 small rocks, which were approximately $20 \mathrm{~cm}$ in diameter and evenly spaced along each transect, thus providing a representative grab sample for each site. We were able to collect the rocks along each transect from the shoreline to approximately $1 \mathrm{~m}$ deep. Periphyton material from each rock was brushed into a tray with a disposable brush. The periphyton material in the tray was then transferred to a polypropylene bottle and fixed with $20 \%$ ethanol (by volume) to shut down biological processes in the samples. We were interested in preserving only the silica frustules for diatom identification.

Permanent diatom slides from all sampling units (including a replicate from 1 randomly selected sampling unit) were prepared using standard techniques (Sgro and Johansen 1995). The diatom slides were examined using an Olympus B-MAX photomicroscope with Nomarski DIC optics at 1000X. Diatoms were identified to the most specific taxon possible. Counts of approximately 400 valves per slide were made, and relative density for each sample was calculated on this basis. Digital micrographs of all taxa were taken and are on file at John Carroll University (University Heights, $\mathrm{OH}$ ) and at the Mountain Studies Institute (Silverton, CO). Duplicate sets of diatom slides will be retained at John Carroll University and at the Mountain Studies Institute. Excess diatom pellet material has been dried and deposited at the California Academy of Sciences (San Francisco).

\section{Data Analysis}

Alpha diversity (species richness) for a site in this study is defined as the number of species found by counting 400 valves on the sample unit slide. Shannon diversity, which is based on species richness and evenness in a sample unit (Shannon and Weaver 1949), was also calculated for each sample unit slide. Shannon diversity measures the degree of uncertainty 
TABLE 1. Water chemistry parameters used for this study (Simon et al. 2001). Metals values represent dissolved totals. Averaged values are represented for the 14th Street gauge (see methods).

\begin{tabular}{lllcccc}
\hline Site & Date & $\mathrm{pH}$ & $\begin{array}{c}\mathrm{Cd} \\
\left(\mu \mathrm{g} \cdot \mathrm{L}^{-1}\right)\end{array}$ & $\begin{array}{c}\mathrm{Cu} \\
\left(\mu \mathrm{g} \cdot \mathrm{L}^{-1}\right)\end{array}$ & $\begin{array}{c}\mathrm{Fe} \\
\left(\mu \mathrm{g} \cdot \mathrm{L}^{-1}\right)\end{array}$ & $\begin{array}{c}\mathrm{Zn} \\
\left(\mu \mathrm{g} \cdot \mathrm{L}^{-1}\right)\end{array}$ \\
\hline Animas above Eureka & 8 Sep 1997 & 7.74 & 1.97 & 2 & 0 & 558 \\
Animas above Cunningham & 8 Sep 1997 & 7.62 & 0.6 & 0.6 & 149 & 312 \\
14th Street gauge & Aug 2001-2004 & 7.09 & 1.59 & 6.64 & 46.8 & 401.36 \\
Animas above Mineral & 9 Sep 1997 & 7.23 & 1.04 & 1 & 1319 & 487 \\
Animas above Deer & 12 Sep 1997 & 7.28 & 0.81 & 0.8 & 1329 & 615 \\
Animas above Elk & 3 Oct 1997 & 7.5 & 0.66 & 0.7 & 969 & 321 \\
Animas above Needle & 3 Oct 1997 & 7.59 & 0.56 & 0.6 & 751 & 228 \\
Animas above Cascade & 3 Oct 1997 & 7.72 & 0.47 & 0.5 & 640 & 249 \\
Cascade Creek & 3 Oct 1997 & 8.36 & 0 & 0 & 0 & 187 \\
\hline
\end{tabular}

in correctly predicting at random an individual from among a group of $n$ individuals and $s$ species. Gamma diversity is reported as the overall species richness in the collection of sample units. Beta diversity, the amount of variation in the collection of sample units, was calculated by dividing gamma diversity by the average alpha diversity among all sites. An important species index (ISI; Ross and Rushforth 1980) was determined by multiplying by 100 the product of percent presence of a species among the samples and the mean relative density of a species among the samples in which it occurs. Important species in the study were defined arbitrarily as those species with an ISI $>2.5$. Only 124 valves were counted on the Deer Creek sample unit slide, so calculations for this site were based on this count.

A Lange-Bertalot index (LBI) score was calculated for each sample unit. LBI species tolerance values were discerned from observations of the Rhine and Main rivers, Germany, as species-specific indicators of organic pollution roughly equivalent to biochemical oxygen demand (BOD; Lange-Bertalot 1979). The LBI was selected because it is used as an assessment tool for rivers in mountainous topography in the western U.S. (Bahls et al. 1993). For each sample, the index was calculated by summing the product of the indicator value assigned to a species by the percent frequency of the species in a sample. Only those species for which there was an LBI indicator value were used in the calculation. An indicator value of 3 was assigned to the most sensitive species, a value of 2 to more tolerant species, and a value of 1 to the most tolerant species. Therefore, theoretically, an index score of 3 would indicate excellent water quality and a score of 1 would indicate poor water quality.
Agglomerative cluster analysis was used to construct a hierarchical classification of the sites. Diatom abundance data was standardized by the norm (Grieg-Smith 1983), and Ward's (1963) linkage method was used with a Euclidean distance matrix of the transformed data. The dendrogram was scaled by the distance function. Groups in the dendrogram were arbitrarily determined by breaking points that seemed appropriate for the goals of the study. Euclidean distance and Ward's linkage were calculated using the $\mathrm{R}$ software package ( $\mathrm{R}$ Development Core Team 2005).

The species that were most representative of each cluster group were determined by indicator species analysis (ISA; Dufrêne and Legendre 1997). Indicator species analysis combines information on species' relative abundance with relative frequency of occurrence in all groups. A maximum indicator value (ISA = 1) is given when all individuals of a species are found in only a single group of sites and when the species occurs in all sites of that group. The species becomes an indicator for the group in which it has the highest calculated indicator value. The likelihood of obtaining this result among the groups by chance is calculated using 1000 Monte Carlo randomizations; the likelihood is reported as a $P$-value. ISA was calculated using the contributed library LABDSV (Roberts 2005) in R (R Development Core Team 2005).

Water chemistry data (Simon et al. 2001) for dissolved $\mathrm{Zn}, \mathrm{Cu}, \mathrm{Cd}$, and $\mathrm{Fe}$, and $\mathrm{pH}$ were obtained in October 1997 above Needle, Elk, and Cascade creeks, and also in Cascade Creek above the Animas River; in September 1997 above Eureka, Cunningham, Mineral, and Deer creeks; and above Cement Creek in August averaged over the years 2001-2004 (Table 1). 


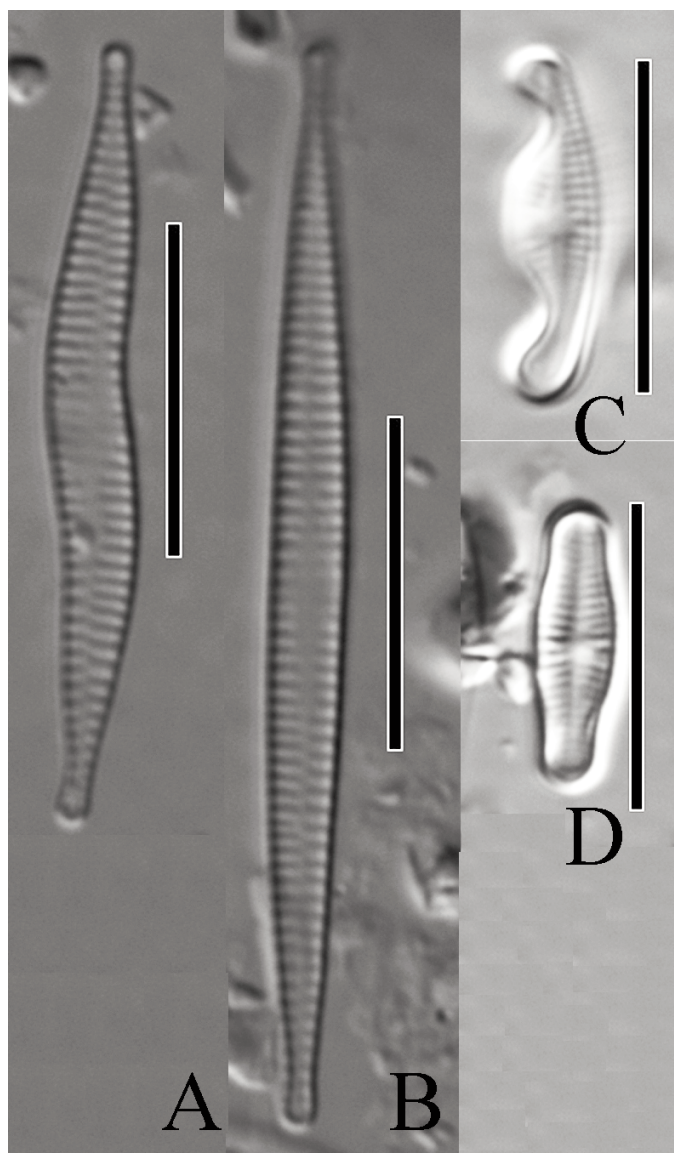

Fig. 1. A, teratologic specimen of Fragilaria capucina var. gracilis; B, normal specimen of Fragilaria capucina var. gracilis; C, teratologic specimen of Achnanthidium minutissimum; D, normal specimen of Achnanthidium minutissimum.

No chemistry data were available for the Cement Creek site above the Animas River. The aim was to select chemistry data from existing data sets that best represented the diatom sample dates and locations used in this study. We selected chemistry samples from recent years that were taken in late summer or fall rather than those which represent spring runoff conditions.

This was the 1st diatom study of the Animas River, and because of the limitations of the dataset, including limited sample size and lack of synoptic chemistry data, we chose a graphical exploratory approach to ecological investigations. The response of diatom community structure to water chemistry was made by examining boxplots. The $\mathrm{Zn}, \mathrm{Cu}, \mathrm{Cd}$, and $\mathrm{Fe}$ data were standardized into zero mean and unit variance using the $R$ software package ( $R$ Development Core Team 2005) with the contributed library Vegan (Oksanen et al. 2005). The standardized values were summed for each site. Boxplots were constructed for the diatom communities defined in the cluster analysis by using the summed metals values, the raw $\mathrm{Zn}$ data, and the $\mathrm{pH}$ values. A plot was drawn such that the box represented the middle "hinges" (nearly quartiles) and the median. The whiskers indicated the largest and smallest observations that fell the distance of 1.5 times the box size from the nearest hinge. Outliers were indicated separately (R Development Core Team 2005). Cement Creek was omitted from this analysis.

\section{Results}

The 80 diatom taxa identified in this study (gamma diversity) represented 32 genera (Table 2). The average alpha diversity per sample was 20 . The overall variation among the sample units (beta diversity) was 4.0. Shannon diversity was relatively low (average per site $=1.16$, average among all sites $=1.44$; Table 3 ). The most important species in the samples were Achnanthidium minutissimum (Kütz.) Czarn. (ISI = 7.2); Encyonema silesiacum (Bleisch in Rabh.) D.G. Mann (ISI = 3.1); Aulacoseira distans (Ehr.) Simonsen (ISI = 2.7); Hannaea arcus (Ehr.) Patrick (ISI = 2.8); and Diatoma mesodon (Ehr.) Grun (ISI = 2.5). Teratologic specimens (specimens exhibiting developmental abnormalities) of Fragilaria and Achnanthidium were present in the Animas River upstream from the Eureka, Cunningham, Mineral, Elk, and Cascade samples (Fig. 1). This study focused on the diatom algae; however, the only nondiatom macroscopic mats of algae observed during diatom collection were those of Hydrurus foetidus (Villars) Trevisan (Chrysophyceae) at the Cascade Creek site.

The highest LBI scores (indicating highest percentage of pollution-sensitive organisms, and thus lowest levels of pollution) were recorded from Cascade Creek $(\mathrm{LBI}=3.00)$ and from the Animas River upstream from Cascade Creek $(\mathrm{LBI}=3.00)$. The lowest LBI score was recorded from Cement Creek upstream from the Animas River $(\mathrm{LBI}=2.92)$. This assessment is based on 15 taxa from our species list that have assigned Lange-Bertalot values. Overall LBI scores were very high in these 
TABLE 2. Diatom species collected from the 10 Animas River sites sampled in this study. FREQ is the percentage of sites in which the taxon occurs; ISI is the important species index (FREQ * mean percent density).

\begin{tabular}{|c|c|c|}
\hline Species & FREQ & ISI \\
\hline Achnanthes kriegeri Krasske & 0.1 & 0.000995 \\
\hline Achnanthes laevis $\emptyset$ st. & 0.1 & 0.000499 \\
\hline Achnanthes petersonii Hust. & 0.3 & 0.001016 \\
\hline Achnanthidium biasolettiana (Grunow) L. Bukht. & 0.1 & 0.000253 \\
\hline Achnanthidium microcephalum Kütz. & 0.2 & 0.007334 \\
\hline Achnanthidium minutissimum (Kütz.) Czarn. & 1.0 & 0.719659 \\
\hline Adlafia minuscula (Grun.) Lange-Bert. & 0.4 & 0.005371 \\
\hline Amphora pediculus (Kütz.) Grun. & 0.1 & 0.001613 \\
\hline Aulacoseira distans (Ehr.) Simonsen & 0.4 & 0.027358 \\
\hline Brachysira vitrea (Grunow) R. Ross & 0.3 & 0.001226 \\
\hline Caloneis bacillum (Grunow) Cleve & 0.7 & 0.005384 \\
\hline Chamaepinnularia soehrensis (Krasske) Lange-Bert. & 0.2 & 0.001306 \\
\hline Chamaepinnularia soehrensis var. muscicola (Krasske) Lange-Bert. \& Kram. & 0.1 & 0.000539 \\
\hline Cocconeis placentula var. lineata (Ehr.) V.H. & 0.5 & 0.001509 \\
\hline Cosmioneis pusilla (W.Sm.) D.G. Mann \& Stickle & 0.2 & 0.00075 \\
\hline Craticula cuspidata (Kütz.) D.G. Mann & 0.2 & 0.000792 \\
\hline Cyclotella stelligera (Cleve \& Grun.) V.H. & 0.1 & 0.000539 \\
\hline Cymbella affinis Kütz. & 0.2 & 0.002745 \\
\hline Diadesmis contenta (Grun.) D.G. Mann & 0.1 & 0.000759 \\
\hline Diatoma mesodon (Ehr.) Grun. & 0.6 & 0.025193 \\
\hline Diatoma moniliformis Kütz. & 0.1 & 0.000498 \\
\hline Diatoma tenue Ag. & 0.2 & 0.001819 \\
\hline Diatoma sp. 1 & 0.1 & 0.000249 \\
\hline Diploneis sp. 1 & 0.1 & 0.000506 \\
\hline Encyonema minutum (Hilse ex Rabh.) D.G. Mann & 0.2 & 0.001004 \\
\hline Encyonema silesiacum (Bleisch in Rabh.) D.G. Mann & 0.9 & 0.031034 \\
\hline Eunotia exigua (Bréb.) Rabh. & 0.4 & 0.016041 \\
\hline Eunotia septentrionalis Østrup & 0.1 & 0.000270 \\
\hline Eunotia muscicola var. tridentula Nörpel \& Lange-Bert. & 0.2 & 0.001045 \\
\hline Eunotia steineckii J.B. Petersen & 0.3 & 0.007215 \\
\hline Eunotia sp. 1 & 0.1 & 0.000995 \\
\hline Fallacia indifferens (Hust.) D.G. Mann & 0.1 & 0.000249 \\
\hline Fallacia vitrea (Øst.) D.G. Mann & 0.1 & 0.000539 \\
\hline Fragilaria capucina Desm. & 0.6 & 0.006383 \\
\hline Fragilaria capucina var. gracilis (Østrup) Hust. & 0.6 & 0.005635 \\
\hline Fragilaria exigua var. 1 & 0.1 & 0.000253 \\
\hline Fragilaria exigua Grunow & 0.1 & 0.001348 \\
\hline Fragilaria sp. 1 (found only in replicate sample) & - & - \\
\hline Fragilaria vaucheriae (Kütz.) J.B. Petersen & 0.8 & 0.016922 \\
\hline Gomphonema angustatum (Kütz.) Rabh. & 0.4 & 0.003035 \\
\hline Gomphonema angustum Ag. & 0.1 & 0.000995 \\
\hline Gomphonema anjae Lange-Bert. \& Reich. & 0.4 & 0.003844 \\
\hline Gomphonema minutum (Ag.) Ag. & 0.2 & 0.001018 \\
\hline Gomphonema olivaceum var. 1 & 0.1 & 0.000498 \\
\hline Gomphonema olivaceum (Lyngb.) Kütz. & 0.1 & 0.000249 \\
\hline Gomphonema pumilum (Grun.) Reich. \& Lange-Bert. & 0.1 & 0.000976 \\
\hline Hannaea arcus (Ehr.) Patrick & 0.7 & 0.027622 \\
\hline Luticola mutica (Kützing) D.G. Mann & 0.2 & 0.000519 \\
\hline Martyana sp. 1 & 0.1 & 0.000244 \\
\hline Mayamaea agrestis (Hust.) Lange-Bert. & 0.1 & 0.000249 \\
\hline Mayamaea atomus (Kütz.) Lange-Bert. & 0.1 & 0.000809 \\
\hline Mayamaea atomus var. permitis (Hust.) Lange-Bert. & 0.1 & 0.000249 \\
\hline Meridion circulare (Grev) Ag. & 0.7 & 0.012987 \\
\hline Navicula bremensis Hust. & 0.1 & 0.001613 \\
\hline Navicula cryptocephala Kütz. & 0.2 & 0.000995 \\
\hline Navicula tantula Hust. & 0.7 & 0.009898 \\
\hline Navicula tenelloides Hust. & 0.2 & 0.000783 \\
\hline Navicula sp. 1 & 0.1 & 0.000249 \\
\hline Navicula sp. 2 & 0.1 & 0.000249 \\
\hline
\end{tabular}


TABLE 2. Continued

\begin{tabular}{lcc}
\hline Species & FREQ & ISI \\
\hline Nitzschia bacillum Hust. & 0.1 & 0.000243 \\
Nitzschia fonticola Grun. & 0.1 & 0.000499 \\
Nitzschia frustulum (Kütz.) Grun. & 0.2 & 0.000985 \\
Nitzschia frustulum var. 1 & 0.1 & 0.000506 \\
Nitzschia palea (Kütz.) W.Sm. & 0.2 & 0.001483 \\
Nitzschia perminuta (Grun.) M. Perag. & 0.1 & 0.000499 \\
Nitzschia pusilla (Kütz.) Grun. emend. Lange-Bert. & 0.3 & 0.004726 \\
Nitzschia sp. 1 & 0.1 & 0.000249 \\
Nitzschia sp. 2 & 0.1 & 0.000499 \\
Nitzschia sp. 3 & 0.1 & 0.000253 \\
Pinnularia appendiculata (Ag.) Cleve & 0.4 & 0.006052 \\
Planothidium frequentissimum (Lange-Bert.) Round \& L. Buk. & 0.2 & 0.000788 \\
Planothidium lanceolatum (Bréb.) Round \& Bukht. & 0.3 & 0.00132 \\
Psammothidium helveticum (Hust.) L. Bukht. \& Round & 0.1 & 0.000809 \\
Pseudostaurosira brevistriata (Grun.) D.M. Williams \& Round & 0.1 & 0.00027 \\
Reimeria sinuata (W. Greg.) Kociolek \& Stoermer & 0.4 & 0.002907 \\
Staurosira construens (Ehr.) D.M. Williams \& Round & 0.2 & 0.000741 \\
Staurosirella pinnata (Ehr.) D.M. Williams \& Round & 0.6 & 0.010268 \\
Stephanodiscus hantzschii Grun. & 0.3 & 0.000991 \\
Stephanodiscus hantzschii var. tenuis (Hust.) Håk. \& Locker & 0.1 & 0.000244 \\
Synedra nannana Lange-Bert. & 0.1 & 0.001741 \\
\hline
\end{tabular}

TABLE 3. Alpha and Shannon diversity scores and Lange-Bertalot pollution index scores for sites sampled in this study. All calculations are based on a 400-valve count except the Animas above Deer Creek sample, which is based on a 150-valve count. Sites are listed from upstream to downstream with tributaries listed last.

\begin{tabular}{lccc}
\hline Site & Alpha diversity & Shannon diversity & LBI score \\
\hline Animas above Eureka & 28 & 1.50 & 2.98 \\
Animas above Cunningham & 22 & 1.01 & 2.97 \\
Animas above Cement & 20 & 1.53 & 2.94 \\
Animas above Mineral & 32 & 1.46 & 2.98 \\
Animas above Deer & 16 & 1.39 & 2.97 \\
Animas above Elk & 26 & 1.49 & 2.96 \\
Animas above Needle & 9 & 0.52 & 2.93 \\
Animas above Cascade & 4 & 0.27 & 3.00 \\
Cement above Animas & 33 & 2.29 & 2.92 \\
Cascade above Animas & 10 & 0.43 & 3.00 \\
\hline
\end{tabular}

samples, indicating little pollution of the type associated with elevated BOD (Table 3).

The agglomerative algorithm grouped the samples by upstream-downstream orientation, except the samples from Cement Creek and from the Animas River above Cement Creek (Fig. 2). Four major clusters were identified. Cluster 1, Cement Creek, represented a diatom flora most unlike the other flora collected in the study. Cluster 2, Animas River above Cement Creek, also represented a somewhat unique flora, though it is more similar to the other major clusters than was the Cement Creek sample. Cluster 3 represented the flora from the 3 samples collected from the lower reach of the study area, and this flora was distinguished from the flora of the samples col- lected above Needle Creek (cluster 4). The species which are most representative of the groups (i.e., the results of the ISA) are presented in Table 4.

An exploratory examination of the effects of water chemistry on diatom community structure was attempted by comparing the major flora types as defined in the cluster analysis with standardized, summed metals data $(\mathrm{Zn}, \mathrm{Fe}, \mathrm{Cu}$, $\mathrm{Cd}), \mathrm{Zn}$ data alone, and $\mathrm{pH}$ measurements. The Cement Creek sample (cluster 1) was removed from this analysis because there were no available chemistry data for this site. The boxplot for the combined metals analysis (Fig. 3) illustrates that there are generally higher metals concentrations for the upstream sample clusters than the downstream cluster. The 
TABLE 4. Significant $(\alpha=0.05)$ indicator species for the defined clusters. The top 3 indicators are listed for cluster 4 , though none are significant.

\begin{tabular}{lllc}
\hline Cluster & Species & $\begin{array}{c}\text { Indicator } \\
\text { value }\end{array}$ & P-value \\
\hline 1 & Mayamaea atomus & 1 & 0.0009 \\
& Psammothidium helveticum & 1 & 0.0009 \\
& Fragilaria exigua & 1 & 0.0009 \\
& Aulacoseira distans & 0.99 & 0.0349 \\
& Eunotia exigua & 0.99 & 0.0359 \\
& Navicula tenelloides & 0.95 & 0.0009 \\
& Pinnularia appendiculata & 0.92 & 0.0309 \\
& Eunotia muscicola var. tridentula & 0.89 & 0.0009 \\
& Nitzschia pusilla & 0.82 & 0.0149 \\
& Gomphonema angustum & 1 & 0.0009 \\
& Mayamaea agrestis & 1 & 0.0009 \\
& Gomphonema olivaceum & 0.33 & 0.0009 \\
& Diatoma moniliformis & 0.33 & 0.0009 \\
& Achnanthidium minutissimum & 0.27 & 0.0019 \\
& Hannaea arcus & 0.59 & 0.0909 \\
& Caloneis bacillum & 0.56 & 0.1838 \\
& Gomphonema anjae & 0.5 & 0.5244 \\
\hline
\end{tabular}

Site Clusters

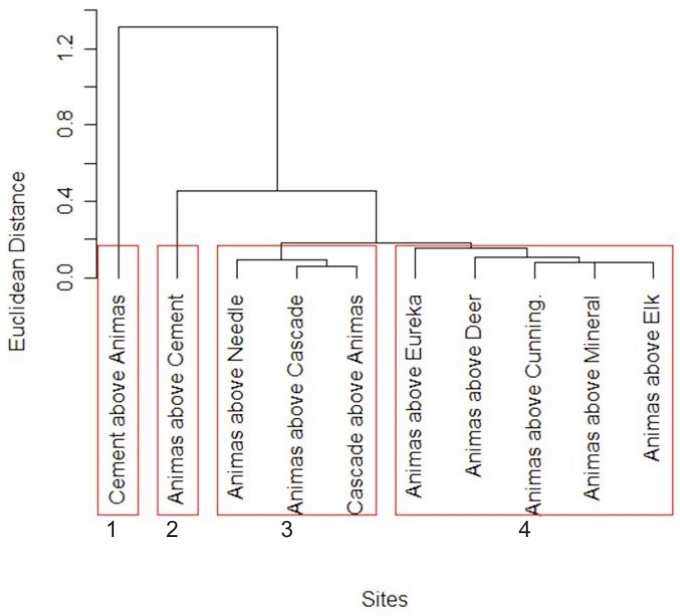

Fig. 2. Ward cluster analysis of Animas River sites based on a Euclidean distance matrix of transformed data on diatom abundance.

metals concentration for the sample taken from the Animas River above Cement Creek appears higher than the metals concentration for the other groups of samples. The plot for $\mathrm{Zn}$ concentration alone separates the downstream cluster, which has a lower concentration of $\mathrm{Zn}$, from the other clusters (Fig. 4). The $\mathrm{pH}$ plot (Fig. 5) shows the downstream cluster to be generally more basic than the upstream clusters, which were more circumneutral at the time of water chemistry sampling.
Metals

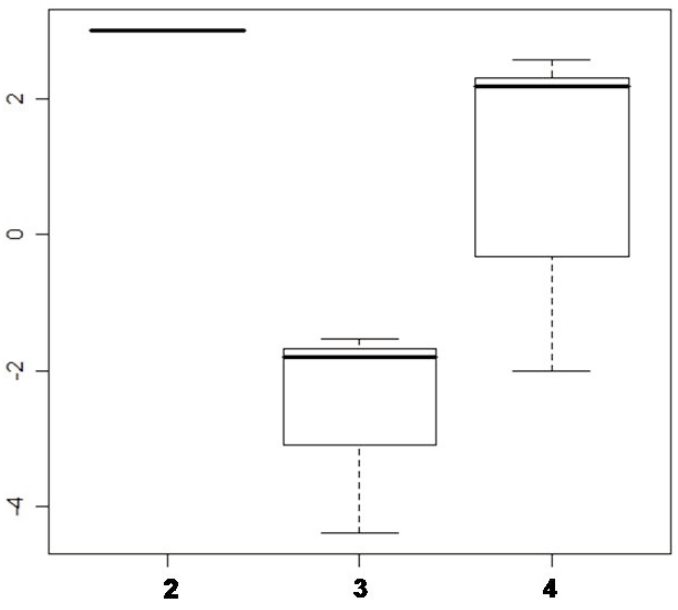

Fig. 3. Plot of combined metals ( $\mathrm{Zn}, \mathrm{Fe}, \mathrm{Cu}, \mathrm{Cd})$ for clusters. Box numbers correspond with cluster numbers in the cluster dendogram. The vertical axis represents values for the standardized summed metals concentrations (see methods).

\section{Discussion}

This survey describes a mountain stream diatom flora of relatively low diversity that reflects conditions of low biological oxygen demand and that is possibly impacted by metals pollution. Differences in concentrations of $\mathrm{Zn}$, or $\mathrm{Zn}$ in combination with $\mathrm{Cd}, \mathrm{Cu}$, and Fe between groups of sites that were defined by 
$\mathrm{Zn}$

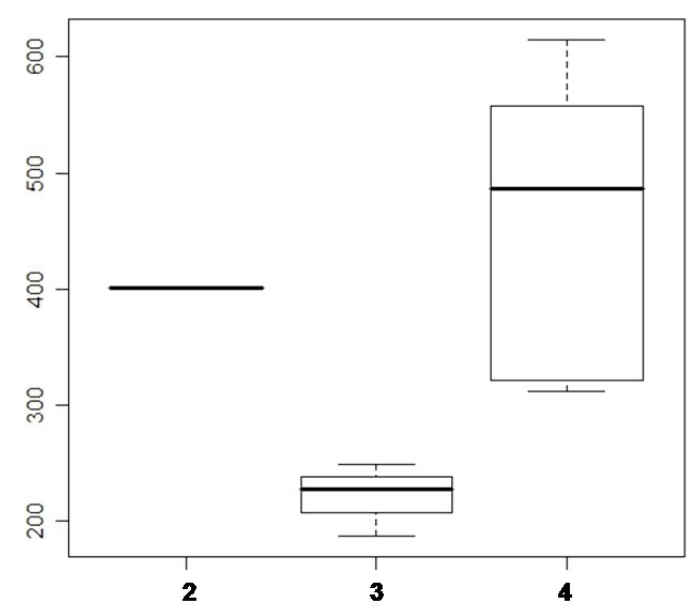

Fig. 4. Plot of $\mathrm{Zn}$ concentrations $\left(\mu \mathrm{g} \cdot \mathrm{L}^{-1}\right)$ for clusters. Box numbers correspond with cluster numbers in the cluster dendogram.

diatom community structure were apparent, suggesting that these metals may influence diatom community structure at the study sites. The 4 distinct diatom communities identified in the study are heavily dominated by Achnanthidium minutissimum, a clean-water indicator, though several specimens of teratologic Achnanthidium and Fragilagia were found. Hypotheses for the low diversity suggested by this study include low resource availability, metals toxicity, and disturbance due to scour.

Nitrogen and phosphorous have been shown in numerous studies to be limiting for diatoms, though changes in community composition due to nutrient limitation are not well understood (see Borchardt 1996 for a review). Though no nutrient data were available for this study, the area soils, which are volcanic in origin, may contain phosphate-rich minerals; thus, nitrogen would most likely be the limiting nutrient for the diatoms at these sites. No green or bluegreen mats, which develop at high concentrations of phosphorus and/or nitrogen, were present. The uniformly high LBI scores, which indicate conditions of very low BOD, also reveal that this is not a highly productive system, having little organic pollution affecting diatom community structure.

Metals concentrations are possibly affecting diatom community composition at our study sites. Zn concentrations or a combination of $\mathrm{Zn}$, $\mathrm{Cd}, \mathrm{Fe}$, and $\mathrm{Cu}$ concentrations appear to differ

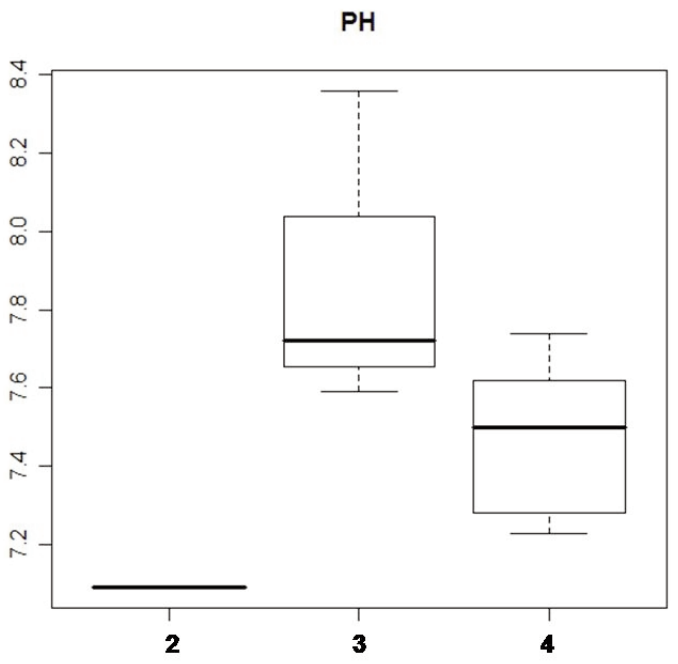

Fig. 5. Plot of $\mathrm{pH}$ values for clusters. Box numbers correspond with cluster numbers in the cluster dendogram.

between groups of sites defined by diatom community composition and could explain differences we noted in the diatom community composition. The most unique diatom community was found in Cement Creek. Though not measured in this study, metal hydroxides clouding the water at this site, unlike other sites, were apparent at the time of diatom sampling. Metals pollution or mechanical disturbances caused by these hydroxides possibly explain the anomalous diatom flora at this site. The Animas River site upstream from Cement Creek developed a flora intermediate between the Cement Creek flora and that of the other Animas River sites, suggesting that this site, too, may be affected by the Cement Creek discharge.

Impacts of heavy metals related to the formation of teratological specimens, such as the ones found at most of the Animas study sites, have been reported in other studies (Feldt et al. 1973, Yang and Duthie 1993). McFarland et al. (1997) reported teratological specimens from the metals-contaminated Eagle River, Colorado. They reported that the best multiple regression model was combined dissolved $\mathrm{Zn}, \mathrm{Cu}$, $\mathrm{Fe}$, and $\mathrm{Cd}$ regressed against frequency of abnormal Fragilaria. They concluded that the frequency of abnormal Fragilaria could be useful as an indicator of metals pollution. Presence of teratological specimens may be a useful indicator of conditions in the Animas River as well; however, it is not known what metals 
concentrations are associated with the presence of these teratological abnormalities in the Animas River.

Heavy metals loading possibly contributes to lowering diatom diversity in the Animas River Watershed. Niyogi et al. (2002) reported that diatom diversity is negatively related to stresses from mine drainage in streams from the Colorado Rocky Mountains but is especially low in those streams with a high concentration of dissolved Zn. Pristine sites that were reported in Niyogi et al. (2002) had dissolved Zn concentrations an order of magnitude lower than those reported in our data for the Animas River Watershed, whereas those of impacted sites ranged to 2 orders of magnitude higher than at our study sites.

The effects of scour at a particular site depend on a variety of local characteristics influencing a diatom community's resilience and resistance to effects of mechanical disturbance; yet, dominance of Achnanthidium in all samples is likely an effect of the fast flow of the Animas River and its tributaries. Achnanthidium minutissimum has been shown by Duncan and Blinn (1989) to reach high densities in fast-flow conditions. The paucity of diatoms in the Deer Creek sample may also be caused by scour, but it is not clear from this study why only this site had low diatom abundance.

Although important species in this study (Achnanthidium minutissimum, Hannaea arcus, and Diatoma mesodon) have broad ranging $\mathrm{pH}$ requirements (Beaver 1981), pH may be affecting diatom distribution in the Animas River Watershed. There are apparent differences in $\mathrm{pH}$ between groups of sites defined by different diatom communities. Hannaea arcus, though reported to have tolerance for high $\mathrm{pH}$ (Beaver 1981), was not found at the Cascade Creek site, which had the highest $\mathrm{pH}$ of the sites in the study.

This study represents the 1st collection of diatom data on the upper Animas River and, consequently, is a benchmark study for future reference. Exploratory analysis in this study reveals that diatom community structure may reflect metals concentrations and $\mathrm{pH}$ differences. Additionally, the presence of teratological specimens can be an indicator of metals pollution in the Animas River. Therefore, diatoms are a potentially useful indicator of changing conditions in the Animas River Watershed due to mitigation efforts or increased pollution loads. Regular sampling of diatom algae can be beneficial for monitoring water quality shifts in the Animas River Watershed.

\section{ACKNOWLEDGMENTS}

This project was funded by a grant from the Mountain Studies Institute (MSI). Bill Simon (Animas River Stakeholders Group) provided water quality data, and he and Koren Nydick (MSI) were consulted on sampling strategy.

\section{Literature Cited}

BAHLS, L.L. 1993. Periphyton bioassessment methods for Montana streams. Water Quality Bureau, Helena, MT.

BEAVER, J. 1981. Apparent ecological characteristics of some common freshwater diatoms. Ontario Ministry of the Environment. 517 pp.

Borchardt, M.A. 1996. Nutrients. Pages 183-227 in R.J. Stevenson, M.L. Bothwell, and R.L. Lowe, editors, Algal ecology. Academic Press, San Diego.

Dufrêne, M., AND P. Legendre. 1997. Species assemblages and indicator species: the need for a flexible asymmetrical approach. Ecological Monographs 67: 345-366.

DUNCAN, S.W., AND D.W. BLINN. 1989. Importance of physical variables on the seasonal dynamics of epilithic algae in a highly shaded canyon stream. Journal of Phycology 25:455-461.

Feldt, L.E., E.F. Stoermer, and C.L. Schelske. 1973. Occurrence of morphologically abnormal Synrdra populations in Lake Superior phytoplankton. Proceedings of the 16th Conference Great Lakes Research 16:34-39.

Gerritsen, J., And M.L. Bowman. 1994. Periphitic diatom assemblages of high elevation Rocky Mountain lakes: characterization of reference conditions [unpublished]. Tetra Tech, Inc., Owings Mills, MD.

Greig-Smith, P. 1983. Quantitative plant ecology. 3rd edition. Blackwell Scientific, Oxford.

Lange-Bertalot, H. 1979. Pollution tolerance of diatoms as a criterion for water quality estimation. Nova Hedwigia, Beih. 64:285-304.

McFarland, B.H., B.H. Hill, and W.T. Willingham. 1997. Abnormal Fragilaria spp. (Bacillariophyceae) in streams impacted by mine drainage. Journal of Freshwater Ecology 12:141-149.

Niyogi, D.K., W.M. LEWIS, AND D.M. MCKNight. 2002. Effects of stress from mine drainage on diversity, biomass, and function of primary producers in mountain streams. Ecosystems 5:554-567.

Oksanen, J., R. Kindt, and, B. O’Hara. 2005. Vegan. R package. Version 1.6-10.

R Development Core Team. 2005. A language and environment for statistical computing. R Foundation for Statistical Computing, Vienna, Austria. ISBN 3900051-07-0. Available from: http://www.R-project.org

RoberTs, D.W. 2005. Laboratory for dynamic synthetic phenomenology. R package. Version 1.2-1.

Ross, L.E., AND S.R. RUSHFORTH. 1980. The effects of a new reservoir on the attached diatom communities in Huntington Creek, Utah, U.S.A. Hydrobiologia 68: 157-165. 
Sgro, G.V., and J.R. Johansen. 1995. Rapid bioassessment of algal periphyton in freshwater streams. Pages 291311 in F.M. Butterworth, A. Gunatilaka, and M. Eugenia Gonsebatt, editors, Biomonitors and biomarkers as indicators of environmental change. Plenum Press, New York.

Shannon, C.E., and W. Weaver. 1949. The mathematical theory of communication. University of Illinois Press, Champaign.

Simon, W., P. Butler, And R. Owen. 2001. Use attainability analysis for the Animas River Watershed. Animas River Stakeholders Group.

Stevenson, R.J., AND R.L. Lowe. 1986. Sampling and interpretation of algal patterns for water quality assessments. Pages 118-149 in B.G. Isom, editor, Rationale for sampling and interpretation of ecological data in the assessment of freshwater ecosystems.
ASTM STP 894. American Society for Testing and Materials, Philadelphia, PA.

von Guerard, P., S.E. Church, D.B. Yager, and J.M. BesSER. 2004. The Animas River Watershed, San Juan County, Colorado. Professional paper 1651, USDI United States Geological Survey, final draft.

WARD, J.H. 1963. Hierarchical grouping to optimize an objective function. Journal of the American Statistical Association 58:236-244.

YAnG, J.R., AND H.C. Duthie. 1993. Morphology and ultrastructure of teratological forms of the diatoms Stephanodiscus niagarae and S. parvus (Bacillariophyceae) from Hamilton Harbor (Lake Ontario, Canada). Hydrobiologia 269/270:57-66.

Received 19 May 2006 Accepted 22 March 2007 